\title{
ZLO MAGII W PASTORALNYCH WSKAZANIACH OJCÓW KOŚCIOŁA
}

Chrześcijaństwo rozwijało się w świecie, który nie tylko akceptował praktyki magiczne, ale korzystał z nich w codziennym funkcjonowaniu. Do magii uciekali się władcy antycznej Galii. Dion Chryzostomos († ok. 120) wspomina o druidach, którzy pełnili rolę doradców królewskich. Znający się na magii, biegli we wróżbiarstwie druidzi wywierali ogromny wpływ na decyzje władców. W Irlandii król przemawiał dopiero po druidzie ${ }^{1}$. Tak w Grecji, jak i w Rzymie wróżby miały znaczący wpływ na podejmowanie kluczowych dla państwa decyzji. Tytus Liwiusz († 17) w Ab urbe condita pisał:

„Któż nie wie, że przy auspicjach założono to miasto, przy auspicjach robi się wszystko na wojnie i w czasie pokoju, w domu i w polu?"2

Na magię składało się wiele różnych dyscyplin, wśród których należy wymienić m.in. astrologię, alchemię, wróżbiarstwo, nekromancję, oniromancję czy teurgię ${ }^{3}$. Izydor z Sewillii w Etymologiach omawiając praktyki magiczne wymienia liczne techniki wróżenia: wróżenie z zachowania ptaków - auguria, auspicia $^{5}$, wróżenie z wnętrzności zwierząt - haruspicja ${ }^{6}$, wróżenie z obserwa-

* Ks. dr hab. Paweł Wygralak - adiunkt w Zakładzie Teologii Patrystycznej na Wydziale Teologicznym Uniwersytetu im. Adama Mickiewicza w Poznaniu; e-mail: pawelwyg@amu.edu.pl.

${ }^{1}$ Por. A. Grenier, Historia Galów, tłum. A. Delahaye - M. Hoffman, Gdańsk - Warszawa $2002,256$.

${ }^{2}$ Titus Livius, $A b$ urbe condita 6, 41, ed. W. Weissenborn - H.J. Müller: Titus Livius, $A b$ urbe condita libri, Pars I: Libri I-X, Leipzig 1898, 393-394, tłum. A. Kościółek: Tytus Liwiusz, Dzieje Rzymu od założenia miasta. Księgi VI-X, Wrocław - Warszawa - Kraków - Gdańsk 1971, 49. Por. M. Jaczynowska, Religie świata rzymskiego, Warszawa 1990, 45.

${ }^{3}$ Por. A. Wypustek, Magia antyczna, Wrocław 2001, 307; J. Kracik, Chrześcijaństwo kontra magia. Historyczne perypetie, Kraków 2012, 15-21.

${ }^{4}$ Izydor z Sewilli w Etymologiach (w rozdziale $O$ magach, ed. J. Oroz Reta - M.A. Marcos Casquero: San Isidoro de Sevilla, Etimologías, Madrid 1982, 712-714) omawia również praktyki wróżbiarskie. Wydaje się, że starożytni duszpasterze byli przekonani, że wróżbiarstwo i magia wzajemnie się przenikają.

${ }^{5}$ Por. Isidorus Hispalensis, Etymologiarum lib. VIII 9, 3. Zob. tamże VIII 18-20; L. Winniczuk, Ludzie, zwyczaje i obyczaje starożytnej Grecji i Rzymu, Warszawa 2008, 569-570.

${ }^{6}$ Por. Isidorus Hispalensis, Etymologiarum lib. VIII 9, 2. W technice wróżenia z wnętrzności zwierzęcia, przede wszystkim z wątroby, ważną rolę odgrywał jej specjalnie przygotowany model. Sposób tego rodzaju wróżenia jest znany dzięki odnalezieniu w XIX w. w Placentii modelu owczej 
cji zjawisk atmosferycznych, przede wszystkim w czasie burzy - aeromancja ${ }^{7}$, wróżenie dzięki nawiązaniu kontaktu z umarłymi - nekromancja ${ }^{8}$, wróżenie $\mathrm{z}$ użyciem wody - hydromancja ${ }^{9}$, wróżenie $\mathrm{z}$ wybranych ksiąg - sortes sanctorum $^{10}$, przewidywania biegu życia człowieka na podstawie układu gwiazd $\mathrm{w}$ dniu narodzin - astrologia ${ }^{11}$. Oprócz wskazanych przez biskupa Sewilli świat starożytny znał jeszcze wiele innych metod wróżenia, jak np. ichtyomanteiawróżby z zachowania się ryb w wodzie; pyromanteia - wróżenie ze sposobu palenie się drewna - znaczenie miał tu rodzaj płomienia, wydobywający się $\mathrm{z}$ niego dym, kierunek dymu; meteoromanteia - wróżenie z obserwowanych zjawisk atmosferycznych, przede wszystkim z błyskawic i grzmotów w czasie burzy; kleromanteia - wróżenie z ruchu najrozmaitszych przedmiotów, np. zawieszonych na nitce pierścieni; chiromanteia - wróżenie na podstawie linii na dłoni człowieka; arytmomanteia - wróżenie z cyfrr ${ }^{12}$. Znane były też formy wróżenia, które wymagały przelewu krwi człowieka. Przykładem jest praktyka wróżenia stosowana przez kapłanów na wyspie Anglesey, leżącej u wybrzeży Walii. Kapłani ci wróżyli z krwi jeńców. Także wśród Galów znane były równie okrutne formy wróżenia, polegające na obserwacji konwulsji umierającego jeńca, którego zabijano w przemyślny sposób zadając mu mieczem cios pod żebra ${ }^{13}$.

$\mathrm{W}$ praktykowaniu magii wielkie znaczenie miało wypowiadanie odpowiednich formuł oraz noszenie talizmanów i amuletów ${ }^{14}$, które przynosiły szczęście, chroniły przed urokiem, odczyniały zło. Noszono zatem torquesy, wszelkiego rodzaju bransolety. Magiczne właściwości przypisywano m.in. bursztynowi, koralowi czy agatowi ${ }^{15}$.

Celem praktyk magicznych było zdobycie panowania nad przyrodą, biegiem wydarzeń, losem człowieka ${ }^{16}$. Już z tych założeń wynika, że praktyki magiczne nigdy nie będą do przyjęcia przez chrześcijanina, który swoją ufność pokłada w Bożej Opatrzności.

\footnotetext{
wątroby, pochodzącego z III w. przed Chr., używanego przez haruspików. Na modelu były określono dwie strefy: przyjazną - familaris, i nieprzyjazną - hostilis. Wróżbita porównywał wątrobę zabitego zwierzęcia - najczęściej owcy, z modelem i na podstawie poczynionej obserwacji, wymagającej sporych umiejętności, wypowiadał wróżbę. Zob. D. Musiał, Antyczne korzenie chrześcijaństwa, Warszawa 2001, 226.

${ }^{7}$ Por. Isidorus Hispalensis, Etymologiarum lib. VIII 9, 2.

${ }^{8}$ Por. tamże VIII 9, 11.

${ }^{9}$ Por. tamże VIII 9, 12.

${ }^{10}$ Por. tamże VIII 9, 28. Zob. W.E. Klingshirn, Defining the Sortes Sanctorum: Gibbon, Du Cange, and Early Christian Lot Divination, JECS 10 (2002) 77-104.

${ }^{11}$ Por. Isidorus Hispalensis, Etymologiarum lib. VIII 9, 22-26.

${ }^{12}$ Por. Winniczuk, Ludzie, zwyczaje i obyczaje, s. 569-570.

${ }^{13}$ Por. Grenier, Historia Galów, s. 252.

${ }^{14}$ Por. Isidorus Hispalensis, Etymologiarum lib. VIII 9, 30. Zob. A. Posacki, Encyklopedia zagrożeń duchowych, II, Radom 2009, 30-32.

${ }^{15}$ Por. Grenier, Historia Galów, s. 252.

${ }^{16}$ Por. Posacki, Encyklopedia zagrożeń, s. 20.
} 
W niniejszym artykule pragniemy zastanowić się na czym polega zło magii według starożytnych autorów chrześcijańskich działających w V-VIII wieku.

1. Magia dziełem diabła. Zło magii wynika $z$ oczywistego dla Ojców Kościoła faktu, iż jest ona dziełem diabła, który nie tylko stoi u początku tych praktyk, jako ich inicjator, ale również zawsze w nich uczestniczy. Przekonany był o tym już świat pogański. Powszechnie uważano bowiem, że człowiek nie może uprawiać magii korzystając jedynie z własnych sił. Musiał posiadać wsparcie demona, określanego terminem paredros - siedzący obok. Eleni Pachoumi zauważa, że w Egipcie mag prosił o wsparcie sił nadnaturalnych ${ }^{17}$. Według A. Wypustka pozyskanie demona - sługi, czyli paredrosa, należało do rytuału inicjacji maga ${ }^{18}$. Mag osobiście zabiegał o wsparcie swoich praktyk przez siły demoniczne. Moc maga jest zatem mocą diabelską, pochodzącą wprost od złego ducha. Choć zdarzały się wypadki przywoływania paredrosa w ściśle określonym celu, to jednak najczęściej współpraca ta była stała, a nawet dożywotnia ${ }^{19}$.

Chrześcijanie byli przekonani, że diabeł jest nie tylko inspiratorem wszelkich praktyk magicznych i wróżbiarskich, ale i ich beneficjentem, gdyż zyskuje duszę człowieka ${ }^{20}$.

Jan Chryzostom stwierdzał jednoznacznie, że

„pychą szatana są przepowiednie z lotu ptaków, praktyki wróżbiarskie, przesądy, przestrzeganie pór roku, zabobony, amulety, magiczne zaklęcia"21.

Wszystko to jest dziełem diabelskim. Złotousty przestrzegał neofitów przed korzystaniem z jakichkolwiek praktyk magicznych. Był bowiem przekonany, że jeśli nawet łączą się one z wzywaniem imienia Bożego, to i tak należy widzieć w nich diabelskie dzieło ${ }^{22}$.

Augustyn był pewien, że magowie są ludźmi, których demony osaczyły i uczyniły swoimi uczniami ${ }^{23}$. Aby wypełniać swoje magiczne sztuki zasięgają rady demonów. Również za szatańskie uważał on wszelkie pisma wróżów, przepowiednie, amulety, cudowne leki, zaklęcia, tatuaże, różnorakie przedmioty zawiązywane, zawieszane czy przykładane do ciała ${ }^{24}$. W De civitate Dei stwierdza:

${ }^{17}$ Por. E. Pachoumi, Divine Epiphanies of Paredroi in the Greek Magical Papyri, GRBS 51 (2011) 155-165.

${ }^{18}$ Por. Wypustek, Magia antyczna, s. 309.

${ }^{19}$ Por. tamże, s. 313-315.

${ }^{20}$ Por. Caesarius Arelatensis, Sermo 50, 1.

${ }^{21}$ Joannes Chrysostomus, Catechesis ultima ad baptizandos 6, ed. A. Piédagnel, SCh 366, $232-$ 234, thum W. Kania, w: Św. Jan Chryzostom, Katechezy chrzcielne, U Źródeł Katechumenatu 2, Lublin 1994, 46. Por. P. Szczur, Problematyka społeczna w późnoantycznej Antiochii na podstawie nauczania homiletycznego Jana Chryzostoma, Lublin 2008, 530.

${ }^{22}$ Por. Joannes Chrysostomus, Ad illuminandos 2, 21-22. Zob. Kracik, Chrześcijaństwo, s. 48.

${ }^{23}$ Por. Augustinus, De civitate Dei XXI 6, 1.

${ }^{24}$ Por. tenże, De doctrina christiana II 20, 30. Zob. A. Eckmann, Dialog św. Augustyna ze światem pogańskim w świetle jego korespondencji, Lublin 1987, 130. 
„wszystkie dziwy magów, które słusznie poczytuje się za godne potępienia, są skutkiem nauki i działalności demonów"25.

Augustyn jest przekonany, że złe duchy są tak przewrotne, iż dla osiągnięcia swego celu dopuszczają używania w magii chrześcijańskiej terminologii. $\mathrm{Na}$ talizmanach pojawiają się więc imiona Archaniołów, a w amuletach wersety biblijne ${ }^{26}$. Cezary z Arles przestrzegając swoich wiernych przed korzystaniem z usług magów, nazywa ich wprost „sługami diabła"27. Podobne określenie - ,pomocnicy diabła” - odnosi do duchownych, którzy wręczali wiernym magiczne węzełki (ligaturas) chroniące przed czarami ${ }^{28}$. Dla biskupa Arles wszystko, co magowie zalecają swoim klientom jest "diabelską trucizną"29. Zaś ich przepowiednie to „diabelskie wróżby” ${ }^{30}$. Niemal identyczną opinię wyraził Marcin z Bragi, który wyrzucał swoim słuchaczom:

„zaniechaliście świętego zaklęcia, to znaczy Symbolu Wiary, jaki otrzymaliście na chrzcie, a jest nim: «Wierzę w Boga, Ojca Wszechmogącego» i Modlitwy Pańskiej, to jest «Ojcze nasz, który jesteś w niebie». Natomiast trzymacie się diabelskich zaklęć i czarodziejskich formuł"'31.

W swoim pouczaniu wspomina o praktyce wypowiadania magicznych zaklęć, w których wymienia się imiona demonów. Czyniono to szczególnie w tych formułach magicznych, które miały zaszkodzić jakiemuś człowieko$\mathrm{wi}^{32}$. W ten sposób biskup Bragi jednoznacznie wskazuje, iż siła magii tkwi w mocy diabelskiej. Demon był przywoływany przez maga, aby udzielił mu swoich mocy. Podobne przestrogi kierował do swoich słuchaczy Eligiusz z Noyon. W każdym wypowiadanym zaklęciu widział wzywanie sił diabelskich. Również wszelkie noszone przez ludzi amulety i talizmany uznawał za dzieło szatańskie ${ }^{33}$.

${ }^{25}$ Augustinus, De civitate Dei VIII 19, PL 41, 244, thum. W. Kornatowski: Św. Augustyn, O państwie Bożym, t. 1, Warszawa 1977, 398.

${ }^{26}$ Por. tenże, In Joannis Evangelium tractatus 7, 7. Zob. A. Hamman, Życie codzienne w Afryce Pótnocnej w czasach św. Augustyna, tłum. M. Stafiej-Wróblewska - E. Sieradzińska, Warszawa 1989, 195; W. Kamczyk, Tota paschalis solemnitas. Teologia i duszpasterstwo w kazaniach i homiliach św. Augustyna, Katowice 2012, 62.

${ }^{27}$ Caesarius Arelatensis, Sermo 204, 3, ed. D.G. Morin, CCL 104, 821: „praecantatores velud ministros diaboli fugiant”. Por. P. Wygralak, Stanowisko Kościoła wobec idolatrii i magii na terenach Galii i Hiszpanii w późnej starożytności chrześcijańskiej (VI-VII w.), Poznań 2011, 132.

${ }^{28}$ Caesarius Arelatensis, Sermo 50, 1, CCL 103, 225. Bardzo możliwe, że w węzełkach tych były umieszczone jakieś fragmenty z Pisma Świętego.

${ }^{29}$ Tamże, thum. S. Ryznar: Cezary z Arles, Kazania do ludu, ŹMT 57, Kraków 2011, 290.

${ }^{30}$ Tamże 53, 1, CCL 103, 233, ŹMT 57, 300. Por. Wygralak, Stanowisko Kościoła, s. 132.

${ }^{31}$ Martinus Bracarensis, De correctione rusticorum 16, 6, ed. A.A. Nascimento: Martinho de Braga, Instrução pastoral sobre superstições populares: De correctione rusticorum, Lisboa 1997, 120, tłum. W. Wójcik, w: Marcin z Bragi, Dzieła, Kęty 2008, 211.

${ }^{32}$ Por. Marcin z Bragi, Dzieta, s. 209, nota 59.

${ }^{33}$ Por. Vita Eligii episcopi Noviomagensis II 16, MGH Scriptores rerum Merovingicarum IV 705. 
Cennym uzupełnieniem powyższych wskazań są refleksje Izydora z Sewilli, dla którego magia jest sztuką diabelską (ars daemonorum). Biskup stwierdza:

„pycha sztuk magicznych została przejęta od przewrotnych aniołów”34.

Mag, aby jego działalność osiągała pożądane efekty zaprzysięgał demony ${ }^{35}$. Cała wiedza magów, ich niezwykła moc, wszelkie praktyki magiczne pochodzą prosto z piekła ${ }^{36}$.

2. Magia kultem diabła. Niektórzy z Ojców Kościoła uważali, że uprawianie magii jest nie tylko wystąpieniem przeciwko Bogu, ale jednocześnie kultem samego diabła. Taką myśl odnajdziemy w wypowiedziach św. Augustyna. Wspominając o powstaniu sztuk magicznych biskup Hippony zauważa, że diabłu cześć oddają ludzie, których uwiodły demony i wszczepiły w ich serca tajemną truciznę ${ }^{37}$. W takim rozumieniu kult diabłu oddawaliby ludzie przez niego opętani, którzy utracili wolność i stali się diabelskimi uczniami. Szerzej problem ten widzi Marcin z Bragi. Komentując jego wypowiedzi należy mieć na uwadze środowisko, w którym przyszło mu duszpasterzować. Mieszkańcy Galicji znaleźli się pod silnym wpływem pryscylianizmu, a jednocześnie była to, jak się wydaje, najmniej zewangelizowana część Półwyspu Iberyjskiego, gdzie ciągle jeszcze żywe i pielęgnowane były zwyczaje i praktyki pogańskie $^{38}$. Jego nauczanie musiało zatem być nacechowane z jednej strony otwartością na ludzką słabość, z drugiej zaś wyrazistym przekazem, co jest zgodne $\mathrm{z}$ duchem Ewangelii, a co takim nie jest. Wykazuje więc kaznodzieja, że wszystko, co ma jakikolwiek związek z magią i idolatrią jest kultem diabła.

„Przepowiadanie, wróżenie (z lotu ptaka) i obchodzenie dnia bożków - cóż to jest innego, jak nie kult diabła? [...] Zaklinanie ziół do czarów i wymawianie imion demonów podczas zaklęć - cóż to jest, jak nie kult diabła?"39

Marcin mówi o kulcie diabła przeciwstawiając go kultowi Bożemu. Chrześcijanin w sakramencie chrztu wyrzekł się diabła, wszystkich ,jego obrzędów kultowych i złych uczynków". Dla biskupa Bragi, co już wcześniej zostało ukazane, oczywiste było, że wszelkie praktyki pogańskie tj. idolatria i magia miały u swego początku diabła. A zatem powrót do tego rodzaju praktyk, był

\footnotetext{
${ }^{34}$ Isidorus Hispalensis, Etymologiarum lib. VIII 9, 3, ed. Oroz Reta - Marcos Casquero, s. 713, thum. własne. Por. tamże VIII 9, 31.

${ }^{35}$ Por. tamże VIII 9, 10.

${ }^{36}$ Por. tamże VIII 9, 3; Wygralak, Stanowisko Kościoła, s. 133.

${ }^{37}$ Por. Augustinus, De civitate Dei XXI 6, 1; VIII 19.

${ }^{38}$ Por. L.A. García Moreno, La Iglesia y el cristianismo en la Galecia de época sueva, „Antigüedad cristiana” 13 (2006) 44; M. Wilczyński, Królestwo Swebów - regnum in extermitate mundi, Kraków 2011, 304-307.

${ }^{39}$ Martinus Bracarensis, De correctione rusticorum 16, 2, ed. Nascimento, s. 120, thum. Wójcik, s. 207-209.
} 
rozumiany przez duszpasterzy jako powrót do czasów pogańskich, czyli do kultu diabła.

3. Praktykowanie magii ciężką winą moralną. Skoro u źródeł magii stoi diabeł i moc maga jest siłą demoniczną, to nie należy się dziwić jednoznacznej negatywnej ocenie Ojców Kościoła, którzy klasyfikowali uprawianie i korzystanie z magii jako grzech ciężki. Każdy chrześcijanin, który uprawia magię lub korzysta z usług magów czy wróżbiarzy traci łaskę przyjętego sakramentu chrztu świętego i w ten sposób jednostronnie zrywa przymierze zawarte z Bogiem. Jan Chryzostom kieruje do neofitów słowa pełne mocy i bólu jednocześnie. Uświadamia im, że zawieszanie sobie amuletów, noszenie na głowie żelaznych medali Aleksandra Macedońskiego ${ }^{40}$, uprawianie czarów jest wyrazem niewiary w moc Bożą. Człowiek, który uprawia magię popełnia grzech ciężki, a jest on jeszcze cięższy, gdy w formułach magicznych nadużywa się imienia Bożego ${ }^{41}$. Zdaniem św. Augustyna korzystanie w chorobie z pomocy wróżbiarza, czy astrologa może być określone jedynie jako złorzeczenie $\mathrm{Bogu}^{42}$. W ten sposób człowieka dobrowolnie naraża się na wielki gniew Boga ${ }^{43}$. Biskup Hippony klasyfikował praktykowanie magii jako grzech świętokradztwa ${ }^{44}$. Takim samym określeniem opisał grzech Adama ${ }^{45}$. Jest więc uprawianie magii poważnym wykroczeniem przeciw Bogu. Podobnej klasyfikacji użył wiele lat później Grzegorz Wielki, a także nieznany autor Kazania $o$ świętokradztwach ${ }^{46}$. Według nich wróżbiarstwo należy uznać jako grzech świętokradztwa ${ }^{47}$.

Cezary z Arles choć z pewnością rozumie troskę i rozpacz matek, które stając bezradnie wobec ciężkiej choroby swoich dzieci, korzystają z porad i praktyk magów - uzdrowicieli, to jednak jako pasterz zatroskany o zbawienie wiernych w osądach takich postaw jest bardzo rygorystyczny. Uważa, że kobiety te „szukając zdrowia ciała, znajdują śmierć duszy”48. Wszyscy, którzy

${ }^{40}$ Medale odnoszą się do bitwy stoczonej przez Aleksandra Wielkiego z wojskami hinduskimi pod wodzą Porosa nad rzeką Hydaspes w dzisiejszym Pakistanie w 326 r. przed Chr. Zgodnie z tekstem greckim katechezy chodziło o wykonane z brązu monety. Por. Szczur, Problematyka społeczna, s. 533, przyp. 478.

${ }^{41}$ Por. Joannes Chrysostomus, Ad illuminandos 2, 22.

${ }^{42}$ Por. Augustinus, Enarrationes in PS. 133, 2. Zob. P. Wygralak, Stanowisko Ojców Kościoła wobec magii, w: Wczesne chrześcijaństwo a religie, red. I. Ledwoń - M. Szram, Lublin 2012, 262.

${ }^{43}$ Por. Joannes Chrysostomus, In epistulam I ad Timotheum hom. 10, 3. Zob. Szczur, Problematyka spoleczna, s. 533.

${ }^{44}$ Por. Augustinus, Enarrationes in Ps. 70, 17.

${ }^{45}$ Por. tenże, Enchiridion in Laurentium 45. Zob. J.N.D. Kelly, Początki doktryny chrześcijańskiej, tłum. J. Mrukówna, Warszawa 1988, 270.

${ }^{46}$ Anonymus, Sermo de sacrilegia, PLS 4, 969-973, tłum. M. Olszewski: Anonim, Kazanie o świętokradztwach, „Znak” 50 (1998) nr 515, 73-76.

${ }^{47}$ Por. Gregorius Magnus, Epistula IX 204; Anonymus, Sermo de sacrilegia III 6-7.

${ }^{48}$ Caesarius Arelatensis, Sermo 52, 5, CCL 103, 232, ŹMT 57, 298. 
oddają kult pogańskim bóstwom, którzy korzystają z usług wróżbitów i magów, zdaniem galijskiego kaznodziei

„porzucają światło, a pędzą w ciemność, gardzą Bogiem a wpadają diabłu w objęcia. [...] Chrystusem gardzą, a w świętokradztwo wstępują"

Tak radykalny osąd postawy wiernych korzystających z magii potwierdzi się także w innych wypowiedziach biskupa Arles. Według niego duszę takich ludzi ,przeszyje miecz niewiary” ${ }^{50}$. W kazaniu 54. Cezary użyje jeszcze mocniejszych określeń:

„Ktokolwiek dopuści się tego zła (korzystanie z posługi tzw. zaklinaczy), natychmiast utraci łaskę chrztu i stanie się świętokradcą i poganinem" ${ }^{\text {"1 }}$.

Skutkiem więc uprawienia i korzystania z magii jest ostateczna utrata łaski wiary otrzymanej w sakramencie chrztu. Biorąc dosłownie wypowiedź kaznodziei, można by dojść do wniosku, że chrześcijanin, który oddaje się praktykom magicznym popełnia grzech apostazji. Magia prowadzi go do wyparcia się wiary w Boga. Czy jednak Cezary aż tak surowo oceniał takie uczynki? Trudno to jednoznacznie stwierdzić. W dalszej bowiem części swojej wypowiedzi przestrzega winnych takich grzechów, iż jeśli nie udzielą znaczącej jałmużny i nie podejmą przedłużonej pokuty z pewnością zginą na wieki ${ }^{52}$. Brakuje tu sformułowania jednoznacznego nakazu do podjęcia pokuty kanonicznej, która była wymagana od apostatów pragnących powrócić na łono Kościoła.

Równie radykalnie do problemu podchodzi Marcin z Bragi. Jest to oczywiste mając na względzie zależność biskupa Bragi od Cezarego z Arles. Tym niemniej jego słowa są z pewnością reprezentatywne dla praktyki Kościoła na Półwyspie Iberyjskim. Tonem pełnym wyrzutu Marcin wypomina słuchaczom uwikłanym w praktyki magiczne, że przez swoje zachowanie zrywają przymierze z Bogiem zawarte w sakramencie chrztu.

„Ktokolwiek gardzi znakiem Chrystusowego krzyża, a spogląda na inne znaki, ten postradał znak krzyża, który otrzymał na chrzcie. Podobnie ten, kto trzyma się innych zaklęć wynalezionych przez czarowników i złoczyńców, utracił zaklęcie świętego Symbolu Wiary i Modlitwy Pańskiej, które otrzymał w wierze Chrystusa i podeptał wiarę Chrystusa, dlatego nie może oddawać czci zarazem Bogu i diabłu" 53 .

A zatem świadomy udział we wszelkiego rodzaju praktykach magicznych jest wyparciem się wiary otrzymanej na chrzcie. Biskup Bragi mówi tu o po-

${ }^{49}$ Tamże 53, 1, CCL 103, 234, ŹMT 57, 300. Por. Wygralak, Stanowisko Kościoła, s. 226.

${ }^{50}$ Caesarius Arelatensis, Sermo 50, 1, CCL 103, 225, ŹMT 57, 290.

${ }^{51}$ Tamże 54, 1, CCL 103, 236, ŹMT 57, 303.

${ }^{52}$ Por. tamże.

${ }^{53}$ Martinus Bracarensis, De correctione rusticorum 16, 6-7, ed. Nascimento, s. 120, thum. Wójcik, s. 211. 
deptaniu wiary w Chrystusa. Człowiek, zgodnie z nauką samego Zbawiciela wyrażoną w słowach: „Nie możecie służyć Bogu i Mamonie” (Mt 6, 24), nie może jednocześnie być wierny Bogu i oddawać czci diabłu. Oddawanie czci diabłu w praktykach magicznych traktowane jest jako wyparcie się wiary w Chrystusa. Podobnie uważa autor Kazania o świętokradztwach. I on poucza, że nie jest już chrześcijaninem ale poganinem człowiek, który zasięga rad u wróżbiarzy, kieruje się w życiu horoskopami, nosi amulety i talizmany, wypowiada zaklęcia ${ }^{54}$. Należy jednak zauważyć, że Marcin, podobnie jak wcześniej Cezary z Arles, nie domaga się od człowieka, który uprawiał magię pokuty kanonicznej, a przynajmniej nie wyraził tego jednoznacznie. Według niego pokuta, która jest w takim przypadku konieczna polega na tym,

„żeby człowiek już więcej nie popełniał zła, którego się dopuścił, ale żeby prosił o przebaczenie za poprzednie grzechy, a na przyszłość wystrzegał się, żeby w nie znowu się nie stoczyć" 55 .

Duszpasterze w ocenie praktyk magicznych używali tak wyrazistych sformułowań, aby ukazać ogrom zła jakie niesie ze sobą magia, a jednocześnie, aby w ten sposób zachęcić słuchaczy do porzucenia zgubnych praktyk i do podjęcia drogi nawrócenia.

Nie wszyscy zwolennicy magii widzieli potrzebę nawrócenia. Wśród tej grupy warto zwrócić uwagę na tłumaczenia zwolenników astrologii, którzy byli przekonani, że skoro bieg życia człowieka jest uzależniony od układu gwiazd w chwili narodzin, to człowieka nie można winić za jego złe postępowanie. Zatem, jak to zauważył św. Augustyn, zwolennicy astrologii winę za własne niegodziwości przypisują nie sobie, ale gwiazdom ${ }^{56}$. Problem ten poruszył również Cezary z Arles, który korzystając z wypowiedzi biskupa Hippony ${ }^{57}$ podkreślił, że ludzie w ten sposób się usprawiedliwiający w rezultacie są winni podwójnego grzechu: wiary w przeznaczenie i pychy ${ }^{58}$. Tak myślący człowiek znajduje się $\mathrm{w}$ bardzo trudnej sytuacji - trwa w grzechu ciężkim, a z powodu braku poczucia winy, nie wyznaje popełnionych grzechów i stąd nie może otrzymać łaski przebaczenia ${ }^{59}$. W ten sposób wiara w przeznaczenie prowadzi człowieka do nieuzasadnionego usprawiedliwiania swego złego postępowania, uśpienia wyrzutów sumienia, a w konsekwencji to trwania w grzechu ciężkim.

${ }^{54}$ Por. Anonymus, Sermo de sacrilegia III 5-6; III 9 - IV 14.

${ }^{55}$ Martinus Bracarensis, De correctione rusticorum 17, 4, ed. Nascimento, s. 122, thum. Wójcik, s. 213.

${ }^{56}$ Por. Augustinus, Sermo 99, 3, PL 38, 1027. Zob. Hamman, Życie codzienne, s. 200.

${ }^{57}$ Por. Augustinus, Enarrationes in Ps. 91, 3.

${ }^{58}$ Por. Caesarius Arelatensis, Sermo 59, 2.

${ }^{59}$ Por. tamże. 
4. Magia uzależnia i zniewala człowieka. Ojcowie Kościoła obserwując chrześcijan oddających się praktykom magicznym i wróżbom byli przekonani, że ludzie ci utracili dar wolności, uzależniając niemal każdą decyzje od wskazań maga czy wyniku wróżby. Chrześcijanin, który bezgranicznie ufa wróżbitom faktycznie staje się według Jana Chryzostoma ich niewolnikiem. Stawia bowiem wyżej wróżbitę niż Boga, i pozwala mu manipulować swoim własnym życiem ${ }^{60}$. W jednym z swoich kazań użyje Antiocheńczyk jeszcze mocniejszych słów mówiąc o ,władzy” horoskopu i podkreślając, że człowiekiem, który zaufał horoskopom demon obraca jak chce ${ }^{61}$. Potwierdza to Augustyn. Omawiając problem korzystania przez chrześcijan z usług astrologów zauważa:

„Ktokolwiek wchodzi jako człowiek wolny do takiego matematyka, płaci, żeby wyjść sługą Marsa, Wenery [...]"62.

Ciekawe jest podkreślenie przez biskupa Hippony faktu zapłaty astrologowi. Człowiek wolny płaci po to, aby dać się zniewolić przez gwiezdne konstelacje. Podobnie zniewalają człowieka wszelakie przesądy. Wiara w nie sprawia, że człowiek przestaje zachowywać się racjonalnie. Augustyn opisuje zachowania człowieka, który w obawie przed czekającym go bliżej nieokreślonym nieszczęściem czuje się zmuszony wejść powtórnie do łóżka tylko dlatego, że wkładając obuwie kichnął albo też wraca „do domu, gdy przy wyjściu człowiek się potknie" ${ }^{63}$. Można sobie wyobrazić, jak osaczony wewnętrznie i zniewolony musi być człowiek, który wierzy w takie i tym podobne przesądy.

O takiej formie zniewolenia mówił w swoich kazaniach również Cezary z Arles. Z jego relacji wynika, że chrześcijanie zasięgali rad wróżbitów w celu podjęcia zwyczajnych decyzji dotyczących wyboru najlepszego dnia na rozpoczęcie podróży i na jej zakończenie ${ }^{64}$. Taka postawa jest wyrazem uzależnienia się człowieka od wyników wróżb. Biskup Arles wyraźnie stwierdzał, że kto uczestniczył w takich ,diabelskich sprawach oddawał się diabłu w niewolę" ${ }^{95}$. Również Marcin z Bragi zwraca uwagę na takie formy uzależnienia. Podobnie jak Cezary będzie więc potępiał praktyki swoich słuchaczy, którzy zwracali uwagę, w jakim dniu rozpocząć podróż, czy też pamiętać, aby małżeństwa zawierać jedynie w piątki, tj. dzień Wenus ${ }^{66}$.

\footnotetext{
${ }^{60}$ Por. Joannes Chrysostomus, In epistulam II ad Timotheum hom. 8, 4. Zob. Szczur, Problematyka spoteczna, s. 530.

${ }^{61}$ Por. Joannes Chrysostomus, In Matthaeum hom. 74, 4, PG 57, 691, tłum. J. Krystyniacki: Św. Jan Chryzostom, Homilie na Ewangelię wedlug św. Mateusza, ŹMT 23, Kraków 2001, 386.

${ }^{62}$ Augustinus, De doctrina christiana II 21, 32, PL 34, 51, tłum. J. Sulowski: Święty Augustyn, O nauce chrześcijańskiej, Warszawa 1989, 85.

${ }^{63}$ Tamże II 20, 31, PL 34, 50, tłum. Sulowski, s. 83.

${ }^{64}$ Por. Caesarius Arelatensis, Sermo 54, 1.

${ }^{65}$ Caesarius Arelatensis, Sermo 54, 5, CCL 103, 239, ŹMT 57, 307.

${ }^{66}$ Por. Martinus Bracarensis, De correctione rusticorum 16, 2.
} 
Szczególną formą zniewolenia człowieka przez diabła jest opętanie. Należy stwierdzić, iż Ojcowie Kościoła walcząc z wszelkimi praktykami magicznymi, bardzo rzadko wspominają o przypadkach opętania ludzi uprawiających magię. Być może można mówić o opętaniu w przypadku opisanym przez Augustyna. Człowiek zostaje zwabiony przez diabła, który używając tajemnej trucizny oferuje mu pozorną przyjaźń. W ten sposób staje się on uczniem diabła ${ }^{67}$.

Również Cezary z Arles wskazuje w kazaniu poświęconym świętowaniu kalend styczniowych na przypadek, który można uznać za opętanie. Do swoich wiernych mówił:

„Przez takie praktyki wciska się ów mistrz zła, by zwolna opanowawszy umysły pod pozorem zabawy, sprawować nad nimi władzę"68.

Istotne jest użyte przez biskupa sformułowanie jasno mówiące o opanowaniu umysłów przez „mistrza zła”, aby „sprawować nad nimi władzę”. Mając na uwadze klasyczną definicję opętania sformułowaną przez R. GarrigouLagrangea $^{69}$, jak również tezę współczesnego egzorcysty O.A. Posackiego, który uważa, że opętanie może być także efektem uprawiania magii ${ }^{70}$, można stwierdzić, że przypadek opisany przez Cezarego jest przykładem opętania człowieka przez diabła. Biskup Arles stykał się, jak to opisują autorzy jego żywota, z osobami opętanymi. Brak jest jednak świadectw, iż opętania te były efektem uprawiania magii ${ }^{71}$.

Tezę, że magia może być przyczyną opętania poświadczają relacje Grzegorza z Tours, który wspomina o wróżce zniewolonej przez złego ducha. Jak pisze starożytny historyk, biskup Verdun, Ageryk, dowiedziawszy się o tej sprawie odprawił nad nią egzorcyzmy, które mimo, że zmusiły złego ducha to ujawnienia się, to jednak nie doprowadziły do całkowitego uwolnienia kobiety ${ }^{72}$. Inny przypadek, opisany także przez Grzegorza, miał miejsce w Paryżu. Pojawiła się tam kobieta, która przepowiedziała pożar miasta. Uważano ją za opętaną przez demona południa ${ }^{73}$. Opętany przez diabła miał

\footnotetext{
${ }^{67}$ Por. Augustinus, De civitate Dei XXI 6, 1.

${ }^{68}$ Caesarius Arelatensis, Sermo 193, 1, CCL 104, 783, thum. własne. Por. Wygralak, Stanowisko Kościoła, s. 230.

${ }^{69}$ Por. R. Garrigou-Lagrange, Trzy okresy życia, Niepokalanów 1998, 894: „Przez opętanie szatan mieszka rzeczywiście w ciele człowieka, zamiast tylko dać mu odczuć swoje działanie od zewnątrz, jak w obsesji. Poza tym, działając wewnątrz, nie tylko przeszkadza on swobodnemu użyciu władz człowieka, lecz sam mówi i działa przez narządy opętanego, tak że ten nie może temu przeszkodzić, a nawet na ogół bez jego wiedzy”.

${ }^{70}$ Por. Posacki, Encyklopedia zagrożeń, s. 178.

${ }^{71}$ Por. Cyprianus - Viventius episcopus, Vita S. Caesarii Arelatensis II 18-19. 20, ed. G. Morin, w: S. Caesarii Opera omnia, II, Maredsous 1942, 332-333. Zob. Wygralak, Stanowisko Kościoła, s. 231-233.

72 Por. Gregorius Turonensis, Historia Francorum VII 44.

${ }^{73}$ Por. tamże VIII 33.
} 
być również wspominany w Historii Franków człowiek pochodzący z okolic Bourges. Przeżył on niezwykłą historię w lesie, gdzie został oszołomiony przez rój much. Zdaniem Grzegorza było to dzieło diabła. Człowiek ten został wówczas opętany przez złego ducha, od którego otrzymał dary przepowiadania i uzdrawiania:

„Wszystko to czynił przy pomocy diabelskich sztuczek i jakiś tam czarodziejstw" "74.

Z biegiem czasu zaczął bluźnić podając się za samego Chrystusa. W tym więc przypadku opętanie nie byłoby skutkiem uprawiania magii. Ów człowiek był opętany, ponieważ został opanowany przez złego ducha i stał się jego narzędziem.

5. Magia prowadzi do wewnętrznej niespójności. Zło magii tkwiło również w podważeniu zaufania do Bożej Opatrzności. Ochrzczeni ludzie potrafili jednocześnie chodzić do kościoła i ufać sztukom magicznym. Ojcowie Kościoła powszechnie potępiali takie postawy. Jan Chryzostom kieruje do neofitów słowa refleksji:

„Powiedz, czy po krzyżu i śmierci naszego Pana mamy pokładać nadzieję naszego zbawienia w wizerunku pogańskiego króla? Nie wiesz, czego dokonał krzyż? Krzyż unicestwił śmierć, zgładził grzech, piekłu wydarł łupy, złamał moc diabła - czyż Mu więc nie zawierzymy, iż może nam On zachować zdrowie ciała?"75

Słuchacze Złotoustego kaznodziei mimo przyjętego sakramentu chrztu nie potrafili zaufać mocy Chrystusowego krzyża. W dalszym ciągu w szczególnie w trudnych chwilach życia, np. w chorobie, uciekali się do porad u magów i korzystali z ich wskazań. W ten sposób sprzeniewierzali się łasce przyjętego sakramentu, gdyż nie potrafili w pełni zaufać i powierzyć się Bogu. Z podobnymi problemami spotykali się również inni duszpasterze. Augustyn podejmuje ten temat w wielu swoich wystąpieniach. Zauważa, że wierni z jednej strony wyznają wiarę w Boga, który daje im życie wieczne, z drugiej jednak strony w sprawach doczesnych szukają wsparcia $\mathrm{w}$ magii ${ }^{76}$. W miarę łatwo jest im trwać przy Kościele, kiedy życie biegnie bez większych problemów. Kiedy jednak takie się pojawiają, zaczynają chwiać się postawy zaufania Panu Bogu:

„być może wtedy dopiero wydają się być chrześcijanami, kiedy ich dom nie doznaje niczego złego; kiedy natomiast jest jakieś strapienie, biegną do wróżbitów, do losów się uciekają, albo do astrologów"77.

${ }^{74}$ Tamże X 25, MGH Scriptores rerum Merovingicarum I/1, 518, tłum. K. Liman - T. Richter: Grzegorz z Tours, Historie. Historia Franków, Kraków 2002, 448.

${ }^{75}$ Joannes Chrysostomus, Ad illuminandos 2, 22, PG 49, 240, thum W. Kania, w: Św. Jan Chryzostom, Katechezy chrzcielne, U Źródeł Katechumenatu 2, Lublin 1994, 67.

${ }^{76}$ Por. Augustinus, Enarrationes in Ps. 88(2), 14; 26(2), 19.

${ }^{77}$ Augustinus, Enarrationes in Ps. 91, 7, PL 37, 1175, tłum. J. Sulowski: Św. Augustyn, 
Biskup Hippony widząc swoich wiernych, którzy w chorobie i wszelkim nieszczęściu korzystają z usług magów, uzdrowicieli pyta: „A gdzie imię Pana?”"78 Augustyn przytacza wypowiedzi takich chrześcijan:

„Niechaj nikt nie mówi: Wprawdzie nawiedzam bożki; opętanych i wróżów się radzę, ale Kościoła nie opuszczam. Jestem katolikiem"779.

Zdaniem A. Hammana postawę taką można określić jak manichejską dychotomię $^{80}$. Biskup Hippony opisuje ją również w jednym ze swoich kazań:

„Są tacy, którzy powiadają: Bóg dobry, wielki, najwyższy, niewidzialny, wieczny, niezniszczalny udzieli nam życia wiecznego i to niezniszczalnego, które przyrzekł w zmartwychwstaniu. Natomiast rzeczy doczesne i światowe należą do demonów i władz ciemności" ${ }^{\prime 1}$.

Przykładów opisów takiej postawy można w wypowiedziach Ojców znaleźć znaczenie więcej. Cezary z Arles w swojej duszpasterskiej posłudze niejednokrotnie spotykał chrześcijan, którzy zasiadali przy stole Pańskim i przy stole demonów ${ }^{82}$, chodząc do kościoła i jednocześnie udając się po pomoc do magów - uzdrowicieli. W takiej postawie upewniało ich przekonanie, że korzystanie z usług magów nie przynosi żadnych negatywnych skutków, wręcz przeciwnie, ich metody leczenia okazywały się bardzo skuteczne. Wielu ludzi tłumaczyło się więc:

„Cóż zrobimy, skoro wróżby i czary czy wieszczkowie bardzo często mówią nam prawdę? [...] Czasem dzieje się tak, że gdy nie ma zaklinaczy, bądź po ukąszeniu węża, bądź w jakiejś chorobie wielu pozostaje w niebezpieczeństwie życia i śmierci" ${ }^{\prime 3}$.

Wypowiedzi te świadczą jak wielkie spustoszenie czyniła w chrześcijanach zewnętrzna skuteczność magii, szczególnie w problemach zdrowotnych. Cezary, jako gorliwy duszpasterz, nie przyjmował takich thumaczeń i odsłaniał swoim słuchaczom całą prawdę o perfidii magii:

„Chociażby ktoś przez te magiczne węzełki odzyskał zdrowie, to będzie je zawdzięczał podstępowi diabelskiemu, który dlatego czasem odejmuje słabość od ciała, ponieważ zdusił już duszę" ${ }^{" 84}$.

Objaśnienia Psalmów (Ps 78-102), PSP 40, Warszawa 1986, 205. Por. Hamman, Życie codzienne, s. 192-193.

${ }^{78}$ Augustinus, Enarrationes in Ps. 91, 7, PL 37, 1175, PSP 40, 205.

${ }^{79}$ Tamże 88(2), 14, PL 37, 1140, PSP 40, 162. Por. Wygralak, Stanowisko Ojców Kościoła, s. 262.

${ }^{80}$ Por. Hamman, Życie codzienne, s. 192.

${ }^{81}$ Augustinus, Enarrationes in Ps. 34(1), 7, PL 36, 327, PSP 37, 354.

${ }^{82}$ Por. Caesarius Arelatensis, Sermo 52, 6.

${ }^{83}$ Tamże 54, 3, CCL 103, 237, ŹMT 57, 305.

${ }^{84}$ Tamże 50, 1, CCL 103, 225, ŹMT 57, 290. 
Chrześcijanin musi więc sobie zdawać sprawę, że nie może jednocześnie być uczniem Chrystusa i korzystać z magii. Cezary podobnie jak wcześniej Augustyn z całą pewnością pamiętał o słowach Chrystusa, który nauczał, że nie można dwom panom służyć (por. Mt 6, 24).

6. Czarna magia i jej skutki. Najczęściej ludzie korzystający z usług magów dostrzegali zewnętrzne korzyści, np. odzyskanie zdrowia. Było to jednak dobro pozorne. W efekcie bowiem człowiek tracił dużo więcej. Jak to zauważał Cezary z Arles, taką „,duszę nieszczęsną przeszyje miecz niewiary”" Człowiek naraża się na utratę zbawienia wiecznego. Ale w zachowanych źródłach znajdziemy również wypowiedzi ukazujące magię jako siłę, która potrafi przywieźć człowieka do utraty zmysłów czy nawet życia lub też zniszczyć jego dobytek. Tym razem sięgniemy do wypowiedzi synodów. Już synod w Elwirze (ok. 306) wspominał o możliwości spowodowania śmierci człowieka przez użycie stosownego zaklęcia ${ }^{86}$. Podobne informacje przynoszą synody zgromadzone w VII wieku: synod w Rouen (650) i XVII synod w Toledo (694). Kanon 4. synodu w Rouen wspomina o magicznych praktykach stosowanych przez pasterzy i myśliwych, którzy dla ochrony swoich zwierząt wywieszali na rozstajach dróg odpowiednio przygotowane talizmany. Jednak praktyka ta służyła jednocześnie spowodowaniu szkody dobytkowi innych ludzi ${ }^{87}$. Natomiast kanon 5. synodu w Toledo mówi o praktyce stosowanej przez niektórych bardzo zdeprawowanych kapłanów, którzy podobno mieli celebrować Mszę św. z formularza o zmarłych w celu zadania śmierci, także wiecznej, konkretnym osobom ${ }^{88}$. Również Izydor z Sewilli utrzymuje, że magowie potrafili pozbawić zmysłów człowieka, a nawet uśmiercić go używając jedynie swoich zaklęc ${ }^{89}$, co potwierdzałoby informacje zawarte w uchwałach synodu w Elwirze.

Ojcowie Kościoła na przestrzeni wieków mieli zbieżne poglądy dotyczące magii. Wszyscy oceniali ją negatywnie, ponieważ byli przekonani, że swoją siłę czerpie z mocy diabelskich. Niektórzy Ojcowie uważali nawet, że magia jest formą kultu diabła. Zatem każdy chrześcijanin, który praktykował magię lub korzystał z usług magów, wróżbitów czy astrologów popełniał grzech ciężki, narażając się w konsekwencji na wieczne potępienie. Chrześcijanin

${ }^{85}$ Tamże.

${ }^{86}$ Por. Concilium Eliberitanum (306) can. 6, SCL I, 51.

${ }^{87}$ Por. Concilium Rothomagense (650) can. 4, Mansi X 1200.

${ }^{88}$ Por. XVII Concilium Toletanum (694) can. 5. Zob. S. McKenna, Paganism and Pagan Survivals in Spain up to the Fall of the Visigothic Kingdom, Washington 1938, s. 133-134; Wygralak, Stanowisko Kościoła, s. 114-115.

${ }^{89}$ Por. Isidorus Hispalensis, Etymologiarum lib. VIII 9, 9. 
zwracając się po pomoc do magów, pytając wróżbitów o przyszłość wykazywał brak ufności w Bożą Opatrzność. Stawał się typowym przykładem człowieka o wewnętrznej niespójności, który zgodnie z obowiązującym dzisiaj przysłowiem chce dać Pan Bogu świeczkę, a diabłu ogarek. Mienił się katolikiem, a jednocześnie swoje mniej czy bardziej ważne decyzje uzależniał od wyniku wróżb, nosił amulety i talizmany, w chwilach choroby szukał wsparcia maga. Dla starożytnych duszpasterzy taka postawa świadczyła o stopniowym uzależnianiu się do magii, co interpretowano powszechnie jako oddawanie się w niewolę diabła i utratę łaski sakramentu chrztu świętego. W ten sposób, zdaniem Ojców Kościoła, chrześcijanin na nowo stawał się poganinem.

Warto jeszcze zwrócić uwagę, że tylko nieliczni Ojcowie Kościoła wspominają o możliwości opętania maga i jego klientów przez diabła. Nieliczni też poświadczają praktykowanie tzw. czarnej magii, której celem było zadanie cierpienia, pozbawienie zmysłów, a nawet życia upatrzonej ofiary. Nie zmienia to jednak ostatecznej oceny magii. Jest ona złem i chrześcijanie nie powinni jej uprawiać, ani też w żadnej sytuacji korzystać z jej pomocy, nawet w najbardziej trudnych sytuacjach życiowych. To wskazanie pozostaje aktualne również w czasach nam współczesnych.

\section{THE EVIL OF MAGIC IN THE PASTORAL RECOMMENDATIONS OF CHURCH FATHERS}

\section{(Summary)}

The article took up the problem of evil in magic in the teaching of the Church Fathers. The ancient priests were convinced that magic was the work of the devil himself. Even the pagan world believed that every mage must have had his own demon, who was the source of their strength. Thus a mage remains at a constant relationship with the devil on whom he is dependent. It can be even said that magic leads inevitably to the worship of the devil. Those who practice magic or seek advice from fortune-tellers and astrologers, put themselves at the devil's disposal, since they make their life decisions dependent on the results of divination or star system. The most serious form of enslavement is demonic possession. Few of the Church Fathers links possession with magic practice, whereas all agree that magic seriously weakens confidence in Divine Providence and leads to a spiritual split, which results in simultaneous participation in the Christian practices and the use of magic services.

Słowa kluczowe: Ojcowie Kościoła, magia, astrologia, zło, niewola, opętanie. Key words: Church Fathers, magic, astrology, evil, enslavement, possession. 